\title{
Studies On The Effectiveness of Mixed Diet of Garden Egg, Groundnut And Garlic With Rat Chow On The Haematological Parameters of Anaemia Induced Adult Wistar Rats.
}

\author{
T. E. Isamoh ${ }_{1}^{*}$, M. A. Eluwa 1 , A. O. Akpantah 1 , T. B. Ekanem 1 \\ 1 Anatomy Department, Faculty of Basic Medical Sciences, University of Calabar, P.M.B.1115, Calabar, \\ Nigeria
}

\begin{abstract}
The use of medicinal plants as food supplements and in the treatment of specific diseases dates back to antiquity. Age old anecdotal reports from many cultures strongly suggests a role for diet of plant origin in preventive and therapeutic medicine. Anaemia remains a major public-health problem especially in developing countries. This study aimed at investigating the antianaemic potentials of combined diet of garlic (Allium sativum), garden egg (Solanum melongena) and groundnut (Arachis hypogaea).Twenty five wistar rats of both sexes weighing 160-200g were divided equally into five groups. Group 1 served as the non-anaemic control and fed with normal rat chow. Groups 2, 3, 4 and 5 were induced with anaemia by oral administration of phenylhydrazine (PHZ) given at 50mg/kgBW. Group 2 served as anaemic control, fed with normal rat chow; Group 3 were fed with $20 \mathrm{~g}(75 \% \mathrm{ww})$ of garlic, garden egg and groundnut in the ratio of 1:1:1 with normal rat chow; Group 4 fed with $10 \mathrm{~g}$ of garden egg (50\%ww) in the ratio 1:1 with normal rat chow and Group 5 fed with $10 \mathrm{~g}$ of ground, nut $(50 \% \mathrm{ww})$ in the ratio 1:1 with normal rat chow. Animals were sacrificed at the end of fourteen days of dietary feeding using chloroform vapour with blood collected at the left ventricle to test for haematological parameters such as red blood cell (RBC) count, white blood cell (WBC) count, hemoglobin concentration $(\mathrm{Hb})$ and packed cell volume (PCV). Results showed that RBC, WBC, Hb and PCV values increased in all the experimental as compared to anaemic control with a significant $(P<0.05)$ in WBC values of groups 3 and 4 as compared to the anaemic control. This suggests a consumption of garlic, garden egg and groundnut will moderately improve anaemic condition.
\end{abstract}

Keywords: anaemia, garlic, garden egg, groundnut, phenylhydrazine, diet

\section{Introduction}

Age-old anedoctal reports from many cultures strongly suggest a role for diet in both preventive and therapeutic medicine (Vaidya and Devasagayam, 2007; Tapsell et al, 2006). Around 60\% of the world's population depends on herbal medicine, a broad term including dietary plants, for primary health care (Modak et al., 2007). Ethnopharmacoligical information has shown that the use of various herbal plants for the treatment of anaemia is common (Akah et al., 2010).

Anaemia is a common blood disorder that is characterised by a reduction from the normal quantity of circulating haemoglobin in the blood, less than $13 \mathrm{~g} / \mathrm{dl}$ for male and less than $12 \mathrm{~g} / \mathrm{dl}$ for female adults (Okochi et al., 2003). Anaemia affects people of all ages, although the people at greater risk are the elderly, young women of child bearing age and the infants. The incidence of anaemia is higher in the third world than in developed countries due to the presence of many aggravating factors such as poor nutrition, low socio-economic status, high prevalence of blood parasites such as Plasmodium and Trypanosomes and helminthic infections. Presently, more than half of the world's population would experience some form of anaemia in their lifetime (Duff, 2008). Also over $50 \%$ of pregnant women and over $40 \%$ of infants worldwide are anaemic with a prevailing significant morbidity and mortality rates particularly in the developing world (Holden and Acomb, 2007). Hence, anaemia is one of the leading health disorders posing a great threat to global healthcare.

Medicinal and dietary plants are currently being used in various parts of the world especially in the tropics for the treatment of various forms of anaemia. Methanol leaf extracts of the leaves of Brillantasia nitens have been shown to improve anaemic condition (Akah et al., 2010). Studies have also shown that M. indica and T. occidentalis leave extracts have antianaemic potential (Ogbe et al., 2010).

Garlic (allium sativum), garden egg (Solanum melongena) and groundnut(Arachis hypogaea) are very common food items in daily Nigerian cuisines as they are cheap and available throughout the year. These plants have been shown to alleviate certain ailments attributed to the various Phytochemical present in them, but no data is available on the combined usage of garlic, garden egg and groundnut diet on anaemia. Thus the need of the present research. 


\section{Breeding of animals}

\section{Materials and Methods}

Twenty five adult wister rats of both sexes weighing between 150-200g were used. They were purchased from the animal house of Department of Physiology, University of Calabar. They were kept in the animal room of the department of Human Anatomy for a period of two weeks under standard conditions of temperature $27^{\circ} \mathrm{C}-30^{\circ} \mathrm{C}$, photo period of 12-hour natural light cycle and 12-hour dark to acclimatize. They were fed with pelleted chick mash manufactured by Agro Feed Mill Nigeria Ltd and drinking water given ad libitum. After the acclimatization period, they were randomly divided into five groups of five rats each; two controls and three experimental groups.

\section{Preparation of the diet}

Garlic, garden egg and groundnut were bought randomly from Watt Market located in Calabar, Cross River State, Nigeria and were identified by the botanist in the botanical garden of the University of Calabar, the plants were washed with water to remove impurities and samples certified as spoiled or attacked by infections were removed. Garlic was defoliated then minced while the garden egg was chopped. The garlic, garden egg and groundnuts were dried in carbolite moisture extraction drying oven (Grant Instruments, Cambridge England) at $50^{\circ} \mathrm{c}$. The groundnut was dried for an hour while the garden egg and garlic were dried for three hours. The now dried samples were blended into coarse powdered form using a kitchen Blender and kept in glass containers with plastic cover to keep them airtight. (Group B-anemic without treatment, C- Feroglobin $0.15 \mathrm{mg} / \mathrm{kg}, \mathrm{D}, \mathrm{E}$ and F- 37.5, 75, and $150 \mathrm{mg} / \mathrm{kg}$ of Solanum torvum extract (STE) respectively daily). The RBC number and hemoglobin concentration were determined using the CELL-DYN 1800 auto analyzer every three days for 24 days.

\section{Experimental protocol}

After the two weeks of acclimatization, the rats were divided into five groups of five rats each and placed of a feeding regimen as follows: (Group 1-non-anaemic control, animals fed with normal rat chow; Group 2-anaemic control, anaemic and fed with normal rat chow; Group 3- anaemic, fed with $20 \mathrm{~g}$ (75\%ww) of garlic, garden egg and groundnut in the ratio of 1:1:1 with normal rat chow; Group 4-anaemic, fed with 10g of garden egg $(50 \% \mathrm{ww})$ in the ratio 1:1 with normal rat chow and group 5-anaemic, fed with 10g of groundnut $(50 \% \mathrm{ww})$ in the ratio 1:1 with normal rat chow). Each of these groups was fed for a period of fourteen days.

\section{Induction of anaemia}

Anaemia was induced by oral administration of phenylhydrazine (PHZ) given at $50 \mathrm{mg} / \mathrm{kgBW}$ for the first two days and then at an interval of three days as maintenance dose. Anaemia was confirmed by test of haemoglobin $(\mathrm{Hb})$ level using haemoglobemeter (Hemocue $\mathrm{Hb} \mathrm{201}^{+}$, Ängelholm, Sweden). Pheylhydrazine is a known haemolysing drug (Goldberg and Stern, 2003).

\section{Collection of blood samples}

The blood samples from the experimental rats were collected by nipping of the rats tails during the course of the experiment and at the end of the fourteenth day of dietary regimen by puncturing the heart at the left ventricle and withdrawing blood using syringe and needle.

\section{Haematological studies}

The blood samples collected served to determine the following haematological parameters: red blood cell (RBC) counts, white blood cell (WBC) count, Hb and packed cell volume (PCV) count using the auto haematology analyser. (Sysmex K21, Auto Hematology Analyser. Tokyo, Japan), (Dacie and Lewis, 1991.). Hb was measured during the course of the experiment by using haemoglobemeter. Blood collected by nipping the rat tail was dropped into the strip. The strip was then inserted into the haemoglobemeter and the $\mathrm{Hb}$ value read off the screen.

\section{Statistical analysis}

This was done using analysis of variance (ANOVA) and post hoc test. All values is expressed as mean \pm standard error of mean (SEM) and values are statistically significant at $\mathrm{p}<0.05$. 


\section{Result}

The drop in $\mathrm{Hb}$ in all the phz treated groups at day 4 indicate onset of anaemia (Table 1, Figure 1). A persistent lowered value of $\mathrm{Hb}$ and $\mathrm{PCV}$ in the anaemic control is an indication of anaemia throughout the duration of experiment. Diet fed animals showed a non-significant $(\mathrm{p}<0.05)$ increase in $\mathrm{Hb}, \mathrm{PCV}$ and $\mathrm{RBC}$ as compared to both anaemic and non anaemic controls (Table 2, Figure 2).

The WBC of animals in group 3 show a significant $(\mathrm{p}<0.05)$ decrease as compared to non-anaemic control and significant $(\mathrm{p}<0.05)$ decrease in animals in group 4 as compared to both anaemic and non anaemic controls.

TABLE 1: Haemoglobin levels on day 1, day 4 of inducing anaemia and termination of experiment.

\begin{tabular}{|c|c|c|c|}
\hline \multirow[t]{2}{*}{ Groups of rats } & \multicolumn{3}{|c|}{$\mathrm{Hb}(\mathrm{g} / \mathrm{dl})$} \\
\hline & Initial & Day 4 & Final day \\
\hline (1) Non anaemic control & $12.86 \pm 0.49$ & $12.9 \pm 0.51$ & $13.6 \pm 0.70$ \\
\hline (2) Anaemic control & $14.2 \pm 0.77$ & $10.6 \pm 0.53$ & $13.44 \pm 0.91$ \\
\hline (3) Fed garlic, garden egg and groundnut & $11.44 \pm 1.40$ & $10.53 \pm 0.87$ & $13.96 \pm 0.21$ \\
\hline (4) Fed garden egg & $13.34 \pm 1.40$ & $10.47 \pm 1.03$ & $14.74 \pm 0.82$ \\
\hline (5) Fed groundnut & $13.56 \pm 1.33$ & $10.22 \pm 0.88$ & $13.66 \pm 0.63$ \\
\hline
\end{tabular}

Values are mean \pm SEM, $n=5$.

TABLE 2: Effect of diet consumption on some haematological parameters of phenylhydrazine induced anaemic rats

\begin{tabular}{lllll}
\hline Groups of rats & $\begin{array}{l}\mathbf{H b} \\
(\mathbf{g} / \mathbf{d l})\end{array}$ & $\begin{array}{l}\text { PCV } \\
(\%)\end{array}$ & $\begin{array}{l}\text { RBC } \\
\left(\times \mathbf{1 0}^{6} \boldsymbol{\mu l}\right)\end{array}$ & $\begin{array}{l}\text { WBC } \\
\left(\times \mathbf{1 0}^{3} \boldsymbol{\mu l}\right)\end{array}$ \\
\hline (1) Non anaemic control & $13.6 \pm 0.70$ & $47.6 \pm 2.92$ & $7.84 \pm 0.43$ & $15.84 \pm 2.73$ \\
& $13.44 \pm 0.91$ & $44.18 \pm 3.05$ & $7.14 \pm 0.49$ & $16.34 \pm 2.04$ \\
(2) Anaemic control & $13.96 \pm 0.21$ & $48.72 \pm 1.13$ & $7.70 \pm 0.31$ & $10.4 \pm 1.26^{\mathbf{a}}$ \\
(3) Fed garlic, garden egg and groundnut & $14.94 \pm 0.67$ & $49.24 \pm 1.76$ & $7.33 \pm 0.53$ & $8.92 \pm 1.74^{* \mathbf{a}}$ \\
(4) Fed garden egg & $14.26 \pm 0.41$ & $49.14 \pm 1.79$ & $7.07 \pm 0.40$ & $12.26 \pm 1.93$ \\
(5) Fed groundnut & & & &
\end{tabular}

Values are mean \pm SEM, $\mathrm{n}=5$.

${ }^{*} \mathrm{p}<0.05$ vs control; $\mathrm{a}=\mathrm{p}<0.05$ vs grp 2

FIGURE 1: Haemoglobin levels on day 1, day 4 of inducing anaemia and termination of experiment.

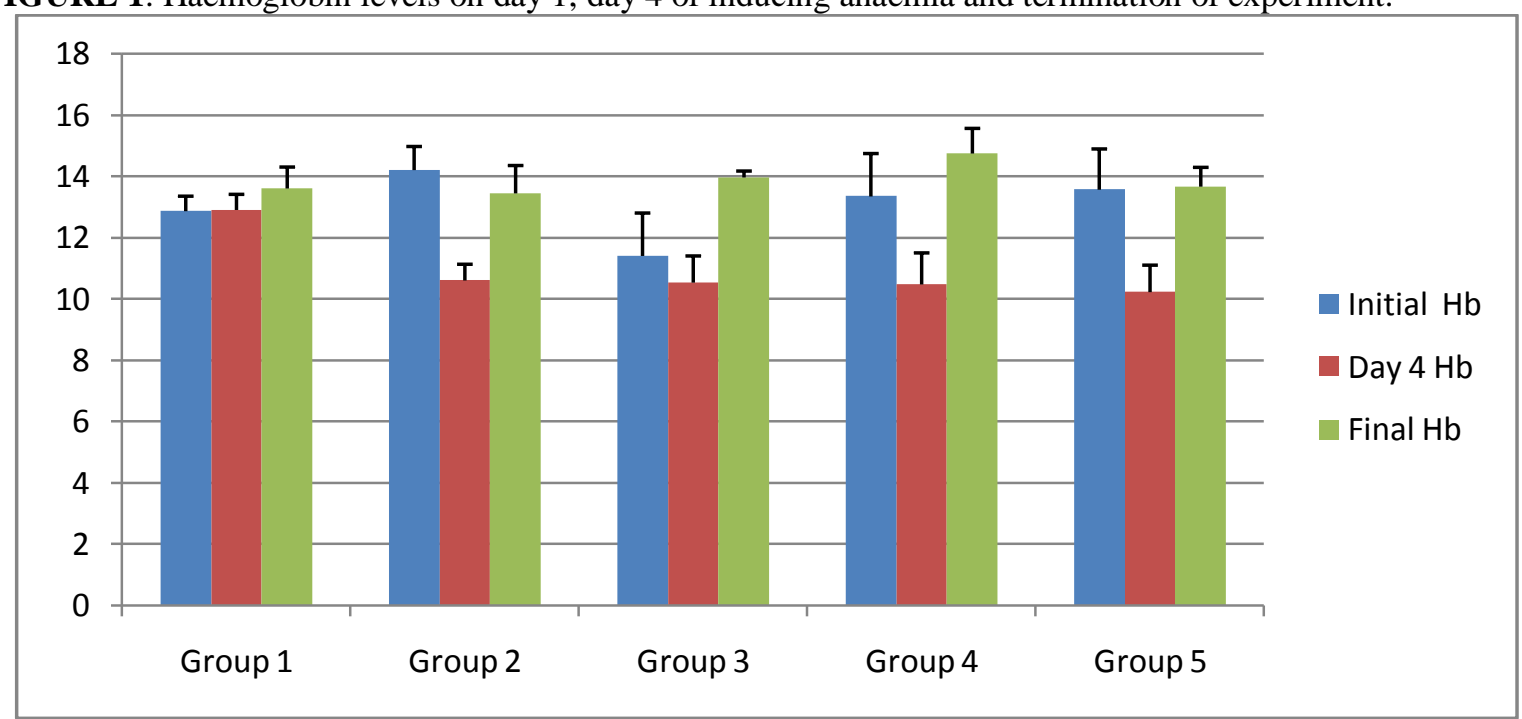

Values are mean \pm SEM, $\mathrm{n}=5$. 
FIGURE 2: Effect of diet consumption on some haematological parameters of phenylhydrazine induced anaemic rats

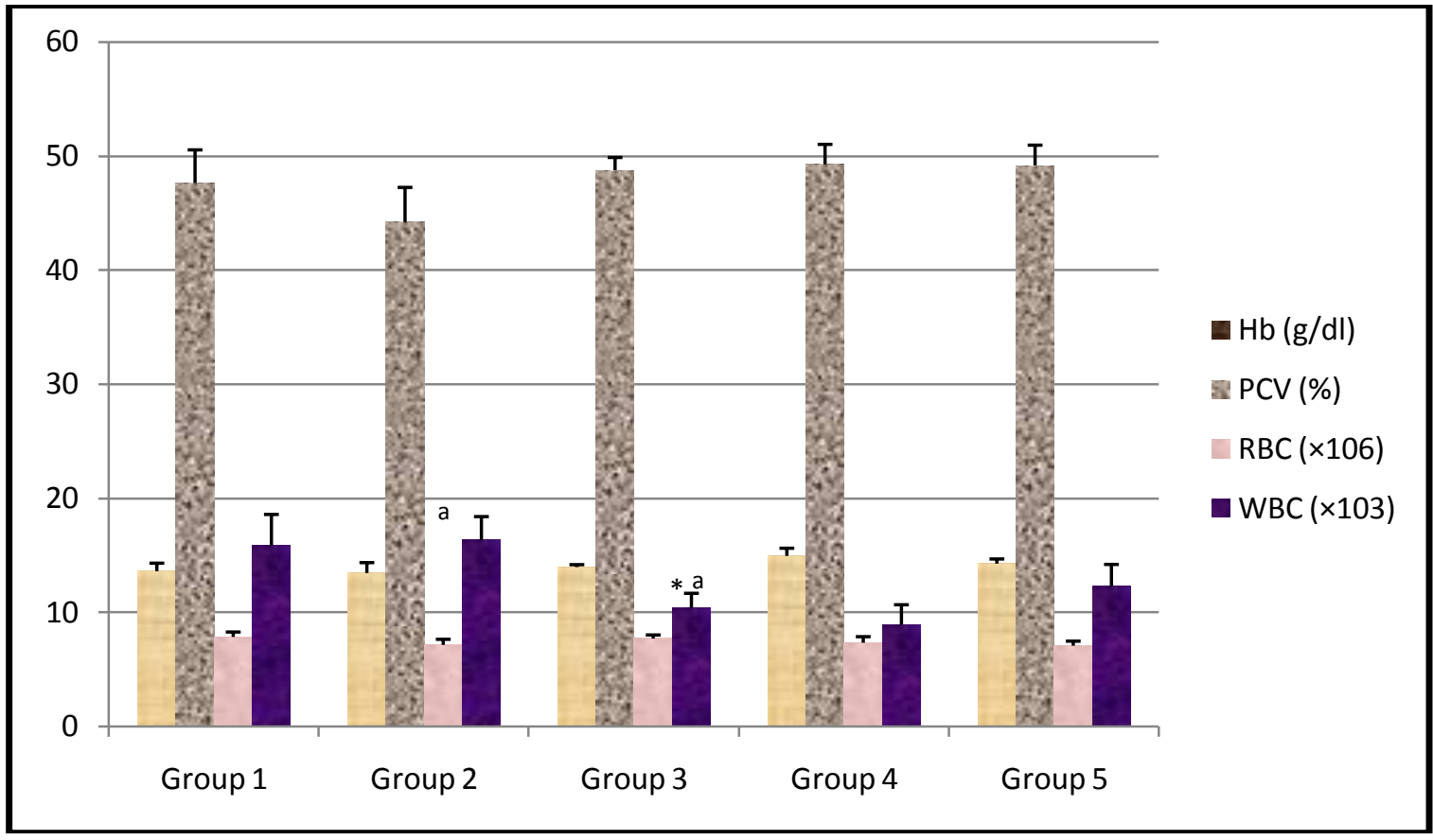

Values are mean \pm SEM, $\mathrm{n}=5$.

$* \mathrm{p}<0.05$ vs control; $\mathrm{a}=\mathrm{p}<0.05$ vs grp 2

\section{Discussion}

Phenylhydrazine has been documented to have the ability of inducing haemolytic anaemia in rats both when administered peritoneally and orally by decreasing the concentrations of blood parameters such as $\mathrm{HB}$, PCV, RBC and WBC (Criswell et al., 2002; O'Riorda et al., 1995). The decrease in concentration of Hb of animals after day 3 of administration of phenylhydrazine at a dose of $50 \mathrm{mg} / \mathrm{kgBW}$ is an indication of anaemia. There seems to be a recovery from anaemia at the end of the experiment by the animal in anaemic control. This could be attributed to a decreasing effect of the drug as the animals went two days without the maintenance dosage (Ogbe et al, 2010).

The slight increase in concentrations of $\mathrm{Hb}$ and PCV and RBC (Table 2) in animals fed with the various dietary feed (grps 3, 4 and 5) as compared to the anaemic and non anaemic controls may be an indication to a mild antianaeamic potentials of garlic, garden egg and groundnut. The antianaemic potential of garlic has been previously reported (Iranloye, 2002).

Garlic, garden egg and groundnut have been documented to contain reasonable amounts of Vitamin $\mathrm{B}_{12}$, folate and other minerals such as Iron and vitamin c (Ayoola and Adeyeye, 2010; Verna et al, 2008; Chen and Li, 2005 and Perry, 1980). These constituents may have contributed in the reversal of the PHZ-induced haemolytic anaemia in the treated groups).

Phenylhydrazine has been reported to cause oxidative damage to red cells by increasing the formation of reactive oxygen species (Clemens et al., 1984; Hill and Thornalley, 1982). Certain Phytochemical including alkaloids, flavonoids and tannins act as antioxidant protecting cells against damage by free radicals. Garlic, garden egg and groundnut has been shown to contain flavonoid, sapponins, phenolics and tannins (Shad et al, 2009; Verna. 2008; Hanson et al., 2006 ; Igwe et al., 2003; Perry, 1980,). This Phytochemical did reverse the adverse effect of phenylhydrazine. The antioxidant property of garlic (Amagase, 2006; Orekhov and Grunwald, 1997; Efendyl et al., 1997), garden egg (Igwe et al., 2003) and groundnut (Shad et al, 2009; Chang, 2006) has been previous reported.

The administration of Phenylhydrazine stimulated increased production of white blood cell in the anaemic control rats (Table 2). This could be a possible stimulation of the immune defence system (Kashinath, 1990; Abdulraham, 2004) as occurred in the anaemic rats. The decrease in values of white blood cell in rats in groups 3, 4 and 5 may be as a result of the antioxidant properties of garlic and garden egg and groundnut as they may act by scavenging the free radicals released by the Phenylhydrazine. Garlic, garden egg and groundnut 
contain vitamin C and Vitamin B complex which are known to boost the body's immune system (Koffuor et al., 2011).

\section{Conclusion}

Result observed in this study indicates that the consumption of garlic, garden egg and groundnut is nutritionally therapeutic and beneficial to anaemic individuals.

\section{References}

[1]. Vaidya, A.D. \& Devasagayam, T.P.A. (2007). Current status of herbal drugs in India: An overview. Journal of Clinical Biochemistry and Nutrition, 41, 1-11.

[2]. Tapsell, L.C., Hemphill, I., Cobiac, L., Patch, C.S., Sullivan, D.R., Fenech, M., Roodenrys, S., Keogh, J.B., Clifton, P.M., Williams, P.G., Fazio, V.A. \& Inge, K.E. (2006). Health benefits of herbs and spices: the past, the present, the future. Medical Journal of Australia, 185, S4-S24

[3]. Modak, M., Dixit, P., Londhe, J., Ghaskadbi, S., Paul, A., Devasagayam, T. (2007). Indian herbs and herbal drugs used for the treatment of diabetes. Journal of Clinical Biochemistry and Nutrition, 40,163-73.

[4]. Akah, P.A., Okolo, C.E., Okoye, T.C \& Offiah, N.V.(2010). Aqueous extract and methanol fractions of leaves of Brillantaisia nitens Lindau. reverses phenylhydrazine-induced anaemia in rats. Journal of Medicinal Plants Research, 4(3), $271-277$.

[5]. Okochi, Y.I., Okpuzor, J. \& Alli, L.A.(2003). Comparison of an African herbal formula with commercially available hematinics. African Journal of Biotechnology, 2(8), 237 - 240.

[6]. Duff, S. (2008). Types of Anaemia. www,innvista.com. Accessed 14-04-2011.

[7]. Holden, J.\& Acomb, C.(2007). Anaemia. In: R.Walker \& C.Whittlesea (Eds.), Clinical Pharmacy and Therapeutics(pp. 699701).New York: Churchil Livingstone.

[8]. Ogbe, R.J., Adoga, G.I. \& Abu, A.H.(2010). Antianaemic potentials of some plant extracts on phenyl hydrazine-induced anaemia in rabbits. Journal of Medicinal Plants Research, 4(8), 680-684.

[9]. Goldberg, B. \& Stern, A.(1977).The mechanism of oxidative hemolysis produced by phenylhydrazine. Academic Press, Inc. New York

[10]. Dacie, J.V. \& Lewis, S.M. (1991).Practical Haematology. 7th Ed. Churchill Livingstone. London. 659-661.

[11]. Criswell, K., Sulhanen, A., Hochbaum, A.F. \& Bleavens, M.(2002). Effect of PHZ or phlebotomy on peripheral blood, bone marrow and erythropoietin in Wistar rats. Journal of Applied Toxicology, 20: 25-29.

[12]. O’ Riordan, D.K., Sharp, P., Sykes, R.M., Epstein, O. \& Debnam, E.S. (1995). Response to PHZ-induced haemolytic anaemia European Journal of Clinical. Investigation, 25:722.

[13]. Iranloye, B. O.(2002). Effect of chronic garlic feeding on some haematological parameters. Journal of Biomedical Research, 81 -82.

[14]. Ayoola, P.B, \& Adeyeye, A. (2010). Effect of heating on the chemical composition and physico - chemical properties of Arachis hypogea (Groundnut) seed flour and oil. Pakistan Journal of Nutrition, 9(8), 751-754.

[15]. Verma, S.K., Jain, V. \& Verma, D. (2008). Garlic - "The spice of life" : composition, cooking chemistry and preparations. Journal of Herbal Medicine and Toxicology, 2(2), 21-28

[16]. Chen, N.C \& Li, H.M. (2005). Cultivation and breeding of eggplant. Asian Vegetable Research and Development Center Shanhua, Tainan. 1-4.

[17]. Perry, L.M.(1980). Medicinal plants of east and Southern Asia. MIT Press, Cambridge.

[18]. Clemens, M.R., Remmer, H. \& Waller, H.D. (1984). Phenylhydrazine-induced lipid peroxidation of red blood cells: in vitro and in vivo monitoring by the production of volatile hydrocarbons. Biochemical Pharmacology, 33:1715-1718.

[19]. Hill, H.A.O. \& Thornalley, P.J. (1982). Free radical production during phenylhydrazine-induced haemolysis. Canadian Journal of Chemistry, 60: 1528-1531.

[20]. Shad, M.A., Perveez, H., Nawaz, H., Khan, H. \& Ullah, M.A. (2009). Evaluation of biochemical and phytochemical composition of some groundnut varieties grown in arid zone of Pakistan. Pakistan Journal of Botany, 41(6), 2739-2749.

[21]. Hanson, P.M., Yang, R.Y., Tsou, C.S., Ledesma, D., Engle, L. \& Lee, T.C. (2006). Diversity in eggplant (Solanum melongena) for superoxide scavenging activity, total phenolics, and ascorbic acid. Journal of Food Composition and Analysis, 19, 594-600.

[22]. Igwe, S. A., Akunyili, D.N. \& Ogbogu, C. (2003). Effects of Solanum melongena (garden egg) on some visual functions of visually active Igbos of Nigeria. Journal of Ethnopharmacology, 86, 135-138.

[23]. Amagase, A., Brenda, L.P., Hiromichi, M., Shigeo, K. \& Yoichi, I. (2001). Intake of garlic and its bioactive components. Journal of Nutrition, 131, 955S-962S.

[24]. Orekhov, A N. \& Grunwald, J,(1997). Effects of garlic on atherosclerosis. Nutrition, 13, 656-663.

[25]. Efendy JL, Simmons DL, Campbell GR, Campbell JH. (1997). The effect of the aged garlic extract, 'Kyolic', on the development of experimental atherosclerosis. Atherosclerosis, 132, 37-42.

[26]. Chang, J.C.(2006). Biosynthesis enhancement and antioxidant and anti-inflammatory activities of peanut (Arachis hypogaea 1.) arachidin-1, arachidin-3, and isopentadienylresveratrol .Journal of Agriculture and Food Chemistry. 54(26),10281-10287

[27]. Kashinath, K.T.(1990). Hypolipidemic effect of disulphide in rats fed high lipids diet and or ethanol. Ph.D. Thesis, University of Bangalore, pp. 221-225.

[28]. Abdulrahman, F.I.(2004). Studies on the chemical contents and pharmacological activities of the root-bark extract on Vitex doniana. African Journal Pharmacy and Pharmacology, 40(3), 163-173.

[29]. Koffuor, G.A., Amoateng, P. \& Andey, T.A. (2011). Immunomodulatory and erythropoietic effects of aqueous extract of the fruits of Solanum torvum Swartz (Solanaceae). International Journal of Pharmacology, 3(2),130-134. 